\title{
Expressing Active Ribozymes in Cells
}

\author{
Dmitry Samarsky ${ }^{1}$, Gerardo Ferbeyre ${ }^{2}$, \\ and Edouard Bertrand ${ }^{3 *}$
}

${ }^{1} \mathrm{HHMI} /$ University of Massachusetts Medical Center, Program in Molecular Medicine, 373 Plantation Street, Worcester, MA 01605, USA

${ }^{2}$ Cold Spring Harbor Laboratory, Cold Spring Harbor, NY 11724, USA

${ }^{3}$ IGMM-CNRS, 1919, Route de Mende, BP5051,

Montpellier, France

\begin{abstract}
Artificially engineered ribozymes can be used to specifically regulate expression of target genes. Such ribozymes can be synthesized chemically and delivered into the cell exogeneously. Alternatively, ribozymes can be produced by the cell endogenously, after introduction of the artificial gene into the cellular genome. In the latter case, the design of the artificial gene defines the ribozyme properties, such as: expression level, intracellular localization, folding and association with proteins. Generally speaking, design of the expression vector is critical to obtain active ribozyme molecules. This paper first describes factors that are known or predicted to affect ribozyme activity in the cell, then reviews various expression systems that have been specifically developed for ribozymes. Lastly, a recently developed ribozyme system termed snorbozymes (small nucleolar RNA:ribozyme hybrids) will be discussed. This powerful test system has generated several important observations that are likely to affect the future development of ribozyme technology.
\end{abstract}

\section{Introduction}

Since their initial discovery in 1982, many types of ribozymes have been characterized (see 1 and 39 for reviews). From the point of view of gene therapy, the most interesting are the hammerhead and the hairpin ribozymes. These ribozymes are relatively small (about 50 bases), and ribozyme-substrate recognition occurs through simple Watson-Crick pairing. It is therefore very easy to engineer new molecules that will cleave specifically any desired target RNA (2). These artificial ribozymes are potentially valuable tools for inactivating specific genes and RNA viruses.

Artificial ribozymes work well in the test tube, and the kinetics and mechanism of the cleavage reaction have been characterized in great detail (see 3 for a review). Despite many attempts to use ribozymes in cells, these attempts have resulted in mixed success, and the resultant activities obtained were often low (4 and references therein). Until very recently, however, there were no in vivo experimental systems where ribozyme activity could be accurately measured.

The first step towards improving ribozymes resides in the characterization of the parameters that can influence the efficiency of the reaction. Such parameters have been described in detail for the in vitro reaction, but have only begun to be unraveled in vivo. They include ribozyme concentration, secondary and tertiary structure and intracellular localization. A second problem lies in the development of cassettes for expressing ribozymes in vivo. Indeed, the design of the expression system influences all of the parameters cited above, and the creation of adequate expression systems is therefore a major challenge toward obtaining ribozymes that are highly active in vivo.

The first part of this paper reviews the parameters that are known to influence ribozyme activity, and will tentatively assess the relative importance of each of these in vivo. The second part describes and discusses attributes of various expression systems currently available. The last section focuses upon a recently described experimental system that allows high ribozyme activity in vivo along with its accurate measurement. The consequences of this work for future ribozyme development will be discussed.

\section{Parameters that Affect Ribozyme Activity}

Many ribozymes has been extensively studied in vitro, and the parameters that affect the cleavage reaction are well known (see 3 for a review). Some of the factors, such as temperature, $\mathrm{pH}$, or $\mathrm{Mg}^{2+}$ concentration, are very general, and these cannot be controlled by the investigator doing ribozyme experiments in vivo. It is worth noting, however, that different types of ribozymes do not have identical requirements. Other factors, such as the length and sequence of the regions that base-pair with the substrate depend on the particular ribozyme motif and the target RNA. In vitro work with hammerhead ribozymes and short substrate molecules has shown that above a certain stability threshold of the ribozyme/substrate complex, usually reached with 10-12 base-pairs of binding sequence, the rate of binding of the ribozyme to its substrate is maximal. Further increase in the length of complementarity, e.g., to 16-20 base pairs, has no effect on the rate of binding, but decreases the rate of ribozyme recycling by slowing down the release of the cleaved products from the ribozyme $(5,6)$. Interestingly, addition of cellular RNA binding proteins such as hnRNPA1 does not change this optimal window of base-pairs, although it does affect the rates of the various reaction steps (7). This suggests that this amount of base-pairing may represent the optimum in vivo as well. Recently, it has been found that the rate of the cleavage step itself can be affected by the region that base pairs with the substrate. Indeed, both a short helix I ( 5 base-pairs), and the sequence A2.1-U2.2 in stem I were found to increase the rate of the cleavage step about 10 fold $(8,9$, numbering as in 10).

Considering the use of ribozymes in cells, the most important parameter is, perhaps, the effect of the sequences that surround the ribozyme. Indeed, most of the in vitro work is performed with very short molecules that do not contain extra non base-pairing flanking sequences. In contrast, expression of ribozymes inside 
cells requires additional sequences that are necessary for the proper processing of the transcript, such as $5^{\prime}$ and $3^{\prime}$ untranslated regions, introns and polyA tails. These extra sequences can diminish ribozyme activity in vitro by as much as 1000 fold $(5,11)$. This inhibitory effect is likely to occur because extra sequences induce the formation of secondary and tertiary structures that interfere with ribozyme efficiency. The extent of such an inhibitory effect in vivo is not known, and may even be less pronounced than in vitro. Indeed, the cell contains many unwinding activities, such as hnRNPA1, that are likely to reduce the stability of inhibitory structures. In any case, results of in vitro studies demonstrate that it is crucial to design the ribozyme expression cassette such that the mature transcript retains maximum activity after folding and binding to cellular proteins. This can be done by either eliminating the potentially inhibitory flanking sequences, or by carefully controlling the structure of the mature transcript and the proteins it associates with.

It is not known for certain which steps of the ribozyme reaction are rate limiting in vivo. Recent work suggested that the cleavage step can occur in vivo at a rate approaching in vitro values $(12,13)$. Furthermore, if one extrapolates from the in vitro situation, it is likely that the rate limiting step in cells is binding of the ribozyme to its target, and this seems to be confirmed by recent in vivo work $(13,14)$. This implies that the ribozyme should be present in vivo at the highest possible concentration. Thus, the expression cassette should provide a high transcription rate as well as stability of the mature ribozyme transcript. Another parameter that cannot be mimicked in vitro, but may have a large influence on the rate of the binding step is the intracellular localization of the ribozyme. In contrast to diffusion limited reactions in a test tube, cells are highly organized. The local concentration of the ribozyme can therefore vary greatly within the cell, depending on the cellular compartment it accumulates in. Thus, colocalization of the ribozyme with its target, or their presence in the same macro-molecular complex, has recently been shown to drastically improve ribozyme efficacy in vivo (13, 14). The ribozyme expression cassette should therefore be carefully designed to maximize intracellular colocalization of the ribozyme with the target. This can be accomplished by including sequences that will direct the ribozyme to the vicinity of the target. The intracellular localization of the ribozyme and its target can be determined experimentally. Since biochemical methods do not provide sufficient resolution, we have appended to this paper a comprehensive protocol for fluorescence in situ hybridization of both mammalian and yeast cells.

To summarize, a few key parameters are thought to determine the ribozyme activity in cells: ribozyme concentration, activity of the fully folded mature RNP, and the degree of co-localization of the ribozyme with its target. These parameters are dependant on the expression system used to synthesize the ribozyme in vivo. In specific attempts to address this problem, a number of different expression cassettes have been designed.

\section{Ribozyme Expression Cassettes}

The ribozyme expression cassettes can be classified according to the promoter used to drive gene expression and the presence of extra sequences that confer new properties to the ribozyme transcript. Investigators have generally used strong promoters to reach the highest possible ribozyme concentration in the cell $(4,15,16)$. Polymerase II (pol II) promoters that are normally involved in the transcription of mRNAs present two important advantages. First, their transcripts are targeted to the cytoplasm, and this might be essential to co-localize with some targets (4). Second, they can be regulated, which is particularly important for studying gene function. In this case, induction of ribozyme expression should be accompanied by the appearance of the phenotype expected from the disruption of the function of the targeted gene, while repression of the ribozyme should revert that phenotype. On the other hand, pol II promoters might be disadvantageous for several reasons. Pol II transcripts are processed as mRNAs for eventual translation. In the case of ribozyme transcripts, this could prevent the ribozyme from freely diffusing to its target, and might also result in the production of toxic peptides. Most importantly, ribozymes expressed from pol II promoters usually contain long stretches of extra sequences that can interfere with proper folding of the catalytic motif.

To avoid the inhibitory effect of the extra sequences, several strategies have been designed to generate ribozymes with well defined flanking sequences. Promoters naturally involved in the synthesis of small RNAs, like tRNAs and snRNAs, have been utilized (4, 5, 17-21). Indeed, these promoters have well defined transcription termination signals, and thus can transcribe short artificial sequences. Specifically, both pol II promoters such as U1 snRNA $(4,5,20)$, and pol III promoters including U6 snRNA, tRNAs and the adenoviral VAI gene have been utilized (1719). Other methods have been used to avoid extra sequences in the ribozyme transcript. For instance, it is possible to include additional, self-cleaving ribozymes on each side of the therapeutic sequence, such that a short molecule is released upon maturation of the primary transcript (22). Another possibility is to use the RNA polymerase of the phage T7 in mammalian cells (23). Whatever the method used to generate a short ribozyme transcript, the problem common to each of these systems is that the resulting ribozymes are often unstable in cells and do not accumulate to high levels $(4,5)$.

To simultaneously avoid the inhibitory effects of flanking sequences, and meet the requirement for RNA stability, carrier RNAs have been developed. The general idea is to include the ribozyme in a larger transcript, i.e. the carrier RNA, which is chosen such that the resulting transcript is stable and adopts a secondary structure that does not inhibit ribozyme activity. It seems that natural ribozymes, such as the ones recently discovered in the parasitic nematode Schistosome mansoni, follow this principle (24). In these unusual transcripts, the hammerhead is transcribed by RNA pol III, but embedded in a larger sequence with a $5^{\prime}$ end very similar to tRNAs. As these transcripts are both active in cis and in trans reactions, one might conclude that these extra sequences do not interfere with catalysis. Thus, such carrier molecules could be used to improve the effectiveness of therapeutic ribozymes in vivo. Other natural RNA molecules have been modified for use as carriers $(4,5,17,18,20,21,25,26)$. This has been done by substituting a region of the RNA known to be accessible to hybridization or to be involved in RNA-RNA interactions with a ribozyme. For instance, 
A

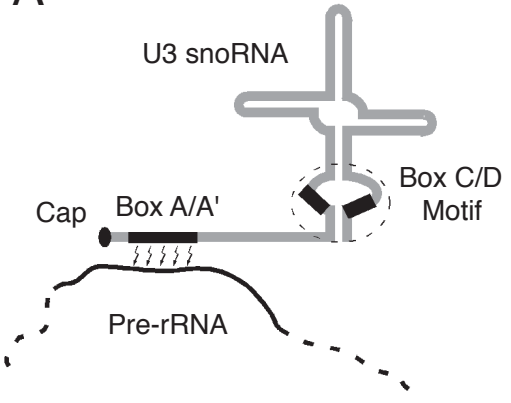

C
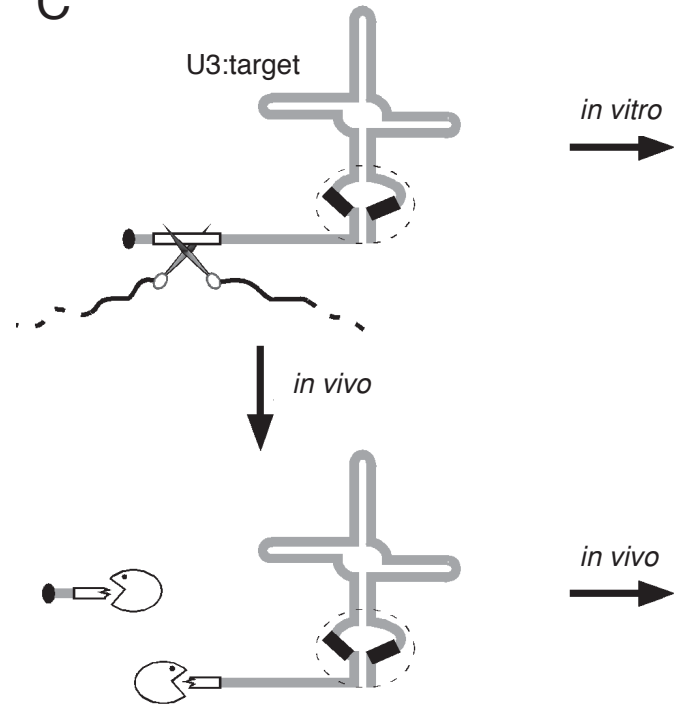

B
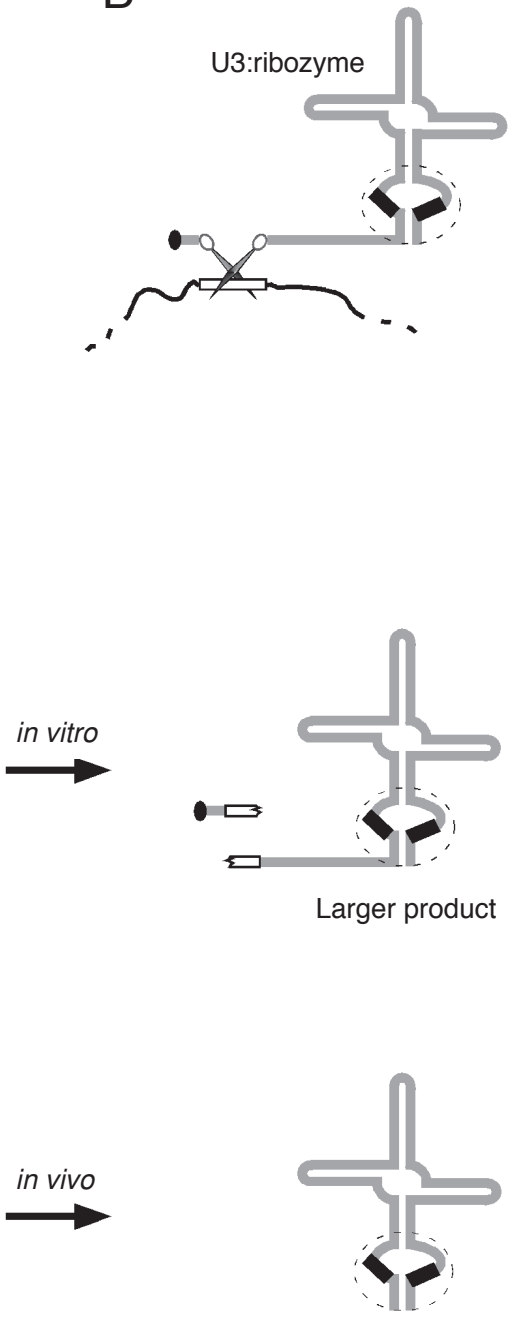

Smaller product
Figure 1. The snorbozyme carrier system. The aim of the snorbozyme system was to demonstrate that small trans-acting catalytic RNAs (e.g. a hammerhead ribozyme) can destroy target RNAs in vivo with $100 \%$ efficiency (see text). The system features U3 small nucleolar RNA as a carrier of both ribozyme and target sequences (hence, the name of the system: snoRNA+ribozyme). A. U3 is a highly conserved snoRNA required for cleavage of the precursor and production of mature rRNAs in precursor and production of mature rRNAs in eukaryotes. The U3 elements essential for snorbozyme design are: 1) the TMG cap, which protects the molecule at the 5 ' side, 2) the universal box C/D motif, which protects RNA at nucleolar localization, and; 3) a segment containing conserved boxes $A$ and $A^{\prime}$ which are normally involved in direct interaction with pre-rRNA. B Insertion of the catalytic sequence in the $5^{\prime}$ portion of U3 in place of boxes A/A' results in RNAstability, nucleolar localization and accessibility for direct RNA-RNA interaction. C. Insertion of the ribozyme target into the 5 ' portion of $U 3$ provides a double-benefit. First, cleavage in this region results in accumulation of an RNA product product which is stable in vivo due to the presence of the box C/D motif. This allows accurate quantitation of both substrate and product molecules. Secondly, as a consquence of endogenous exonucleolytic cleavage, the final product which accumulates in vivo is smaller than that generated in vitro. Thus, the authentic in vivo cleavage product can be easily distinguished from artifacts. the $5^{\prime}$ end of the U1 snRNA is known to accessible to hybridization and to base pair with the 5 ' splice site in the context of the native snRNP particle. Replacing this short sequence with a ribozyme yields a hybrid molecule which is active in vivo (5). Alternatively, carrier RNAs that are completely artificial have also been created by designing the mature transcript such that an artificial secondary structure will form which both exposes the ribozyme and stabilizes the transcript (27).

In addition to the selection of the promoter and suitable stabilizing sequences, recent reports highlight the benefits of fusing the ribozymes to sequences that can enhance its co-localization and its interaction with the target RNA. This was first done by using viral encapsidation signals (14, 28 ), and more recently with a snoRNA (13, see below). In the former system, two retroviruses are used. One serves as a substrate, while the other expresses a ribozyme targeted against it. In the first version of this system, the substrate virus contained the LacZ gene (14). Coexpression of these two viruses into packaging cells greatly reduced the resulting titer of LacZ viruses, as compared to the titer obtained with an inactive ribozyme control. In contrast, the ribozyme was unable to efficiently block translation of LacZ mRNAs in the co-infected cells. Thus, co-packaging of the two viral RNAs in the same virion facilitated the destruction of LacZ viral RNA by the ribozyme. In a second version of this system (28), the substrate virus expressed a hygromycin resistance encoding transcript, while the ribozyme containing virus expressed a neomycin resistance transcript. Cotransfection of these two viral genomes in both packaging and non-packaging cells yielded very few Hygro and NeO doubly resistant clones, as compared to the number of clones obtained with a disabled ribozyme. This activity was further dependant upon the packaging sequence $\psi+$, demonstrating that this sequence was able to mediate ribozyme/target interactions in the cell. Importantly, these interactions take place in the absence of viral proteins and hence in the absence of packaging. Since the $\psi+$ sequence is known to mediate not only packaging, but also viral RNA dimerization via auto-complementary stem-loops (29), it is likely that this mechanism facilitated ribozyme activity in vivo.

In the future, one might predict that new generations of ribozyme expression cassettes will not only produce a ribozyme that is stable, active when folded, and properly 
localized, but will also exploit the concept of protein assisted RNA catalysis (7). Indeed, some RNA-binding proteins enhance ribozyme activity by accelerating the rate of binding to the substrate. Inclusion of these proteins in the RNP formed by the ribozyme in the cell may therefore increase their activity.

\section{Snorbozymes: A Powerful System for Expressing and Studying Ribozymes}

As described above, several factors are thought to affect activity of ribozymes in vivo. These include: 1) stability and abundance of ribozyme molecules; 2) physical accessibility of the relevant ribozyme and target segments for RNARNA interaction, and; 3) precise co-localization of the ribozyme with its target RNA inside the cell. Recently, a novel ribozyme expression system has been described, the snorbozymes (from snoRNA+ribozyme: 13). This new system is easy to manipulate, and permits simple, reliable, sensitive and accurate measurements of the ribozyme cleavage activity.

The major component of the reported snorbozyme system is a snoRNA, U3. SnoRNAs are a large group of RNAs that localize in the nucleolus of eukaryotic cells, and are intimately involved in the complex events of ribosome synthesis (reviewed in 30-32). Several snoRNAs are required for cleavage of the long ribosomal RNA precursor, while many others were shown to be required for sitespecific modifications of rRNA nucleotides. U3 belongs to the so called box C/D snoRNAs, which are mainly involved in 2'-O-methylation of rRNA nucleotides. U3, however, does not seem to be involved in the rRNA nucleotide modification events, but plays a critical role in the early cleavage events of pre-rRNA precursor.

Several features made U3 especially attractive for developing a ribozyme carrier system (Figure 1; see 33). First of all, the size of this RNA is relatively small (333 nt), and its secondary structure is well established (34) Importantly, it is known that a substantial portion of the molecule is available for direct RNA-RNA interaction, i.e. a segment in the $5^{\prime}$ region of the molecule encompassing conserved boxes $A$ and $A^{\prime}$. At the $5^{\prime}$ side, this segment of U3 is protected from exonucleases by a trimethyl guanosine structure (TMG cap). At the $3^{\prime}$ side, it is stabilized by the box C/D motif, composed of box C' (U3 analog of box C) and box $D$ juxtaposed against each other by adjacent stems. In vivo, the box C/D motif is most likely associated with a protein (s) that protects the entire portion between boxes from exonucleolytic degradation (see 35, and references therein). It has been demonstrated that, in addition to providing a stabilizing function, box C/D motif also secures nucleolar localization of the corresponding snoRNA (ibid.). Taken together, these features made it possible to use U3 as both ribozyme carrier and ribozyme target. Indeed, RNA fragments corresponding to a ribozyme or a target, placed in U3 instead of the box A/A' element, should be metabolically stable and available for RNA-RNA interaction. U3 derivatives carrying ribozyme or target RNAs should also co-localize in a relatively small subcellular compartment.

The use of U3 derivatives as targets provides an additional benefit. Thus, when cleavage of the RNA target occurs at the $5^{\prime}$ segment of U3 derivative, the box C/D motif should still protect RNA sequences locked between boxes $C^{\prime}$ and $D$, and this should result in vivo in accumulation of a metabolically stable product. (Figure 1). The product of the ribozyme cleavage reaction that accumulates in vivo should therefore differ from the one obtained in vitro: in vivo, intracellular exonucleases remove a protruding 5 ' portion from the initial product. This way, an authentic in vivo cleavage can be easily distinguished from any artifactual in vitro events, such as cleavage during the RNA isolation/purification procedure. The ability to measure the level of the cleaved substrate also makes in vivo kinetic studies much more accurate and sensitive.

Several important observations were made during the initial testing of the U3-snorbozyme system in Saccharomyces cerevisiae (see 13). First of all, the system behaved as predicted, i.e.: 1) the catalytic and target RNAs were stable; 2) both molecules co-localized in the nucleolus; 3 ) co-expression of ribozyme and target resulted in cleavage of the target, and; 4) a stable, exonucleolytically trimmed byproduct accumulated. Secondly, and most importantly, it was demonstrated that a highly efficient cleavage of the target molecule is possible. Thus, during co-expression of the target and catalytic molecules from low-copy plasmids, $\sim 60 \%$ of the target RNA was cleaved. After over-expression of the catalyst from a multi-copy plasmid and optimization of the ribozyme structure, almost $100 \%$ of the target molecule was specifically converted into the product.

These results opened the doors to novel directions in ribozyme technologies. Precision and simplicity of the snorbozyme system provides a valuable mean for conducting accurate and detailed studies of ribozyme kinetics inside the cell. Thus, preliminary kinetic estimations suggested that the critical step for efficient cleavage is the interaction between ribozyme and target, rather than the cleavage itself (13). Undoubtedly, such studies will help to improve and optimize ribozyme performance in vivo.

The snorbozyme system demonstrated that snoRNAs can serve as reliable and efficient carriers of catalytic RNAs to the nucleolus. This creates the potential for targeting nucleolar RNAs, such as rRNA, and various snoRNAs (it has been estimated that yeast contain $\sim 100$ and humans 200 different snoRNA species; see 30, 31). Remarkably, other types of RNA molecules also reside in the nucleolus (reviewed in 36). The list of such RNAs, transiently or abnormally present in the nucleolus, includes: various mRNAs, RNA component of telomerase, signal recognition particle RNA, U6 spliceosomal RNA and RNA components of MRP and RNAse $P$ ribonucleoproteins. Even some viral RNAs were detected in the nucleolus. In addition, in animal and plant cells, U3 snoRNA has also been found in coiled bodies, and box C/D motif was demonstrated to be sufficient for targeting snoRNAs to this compartment, as well as to the nucleolus (35). These latter findings extend the number of potential snorbozyme targets to all spliceosomal RNAs, which are known to transiently reside in coiled bodies. Thus, the possibility exists that many eukaryotic RNAs can be targeted with snoRNA-carried ribozymes.

The yeast S.cerevisiae, as the best characterized eukaryotic organism, offers enormous potential for characterizing and improving ribozymes in vivo. Particularly attractive in this respect is the possibility of using genetic approaches in yeast. Numerous attempts to recruit S.cerevisiae for ribozyme studies did not produce the 
desired results, however. Inactivation of gene expression in yeast using ribozymes either occurs with very low efficiency, or requires special culturing conditions (see 37 and references therein). Results obtained with snorbozymes disprove pessimistic opinions that S.cerevisiae is an inappropriate host organism for ribozyme studies, and opened new perspectives for employing this valuable species.

Most importantly, the use of snorbozymes in yeast confirmed a long-awaited prediction that trans-acting ribozymes can be used in vivo to efficiently destroy target molecules. The results obtained with the snorbozymes demonstrated that the conditions known to affect the activity of trans-ribozymes in vivo, such as a high concentration of ribozyme molecules, a structure of the ribozyme carrier that is compatible with ribozyme activity, and the colocalization of ribozyme with its target RNAs, are also sufficient for achieving a high efficiency of ribozyme cleavage. This important outcome allows rationalization of the rules for the general design of a highly efficient ribozyme carrier. Such molecule should contain a simple RNA stabilizing element(s), and a localization signal(s) identical to that of the targeted RNA. The catalytic RNA segment should substitute a carrier's portion that is normally involved in RNA-RNA interactions. We strongly believe that by following this design, efficient cleavage of any RNA will become a routine task.

\section{Protocols}

\section{In Situ Hybridization of Mammalian Cells (RNA and Oligonucleotide Probes)}

\section{General Considerations}

In situ hybridization is a powerful technique that can be very informative. It should however be carefully controlled since it can lead to artifacts. One of the most important aspects is fixation. Formaldehyde is widely used as a fixative. Ideally, fixation should be strong enough to prevent loss of material during the hybridization and washing steps, but mild enough to allow the probe to penetrate everywhere in the cell. For this reason, DNA oligonucleotides are among the best probes available. They are short (a 50 base probe is 50 times smaller than the Fab fragment of an antibody), which means that they penetrate very well into cells. They can be washed under mild conditions compatible with th retention of intra-cellular RNA. Short RNA probes (50-100 nt) are similar to oligonucleotides, but they necessitate more stringent washing conditions, and some cellular RNA may be lost at this step since the formaldehyde fixation is not resistant to high temperatures. The only advantage of RNA probes versus oligonucleotides is their lower cost. If RNA probes are chosen, transcripts longer than 200 nucleotides should be avoided.

When performing in situ hybridization for the first time it is often desirable to monitor RNA loss during the procedure by staining the slides with propidium iodide.

\section{Fixation}

Mammalian cells are grown directly onto cover slips, washed once in 1X PBS (100 mM Na $2 \mathrm{HPO}_{4}, 20 \mathrm{mM}$ $\mathrm{KH}_{2} \mathrm{PO}_{4}, 137 \mathrm{mM} \mathrm{NaCl}, 27 \mathrm{mM} \mathrm{KCl}, \mathrm{pH}$ 7.4), and fixed for $10 \mathrm{~min}$ at room temperature in $4 \%$ formaldehyde $(40 \%$ liquid stock purchased from Electron Microscopy Science), $10 \%$ acetic acid, 1 X PBS.
Remark: The presence of acetic acid improves detection of nuclear RNA. It can be replaced by triton extraction prior to fixation. Neither of these treatments is necessary when short ( 50 bases) oligonucleotides probes are used (30 min fixation in $4 \%$ formaldehyde, $1 \mathrm{X}$ PBS is sufficient in this case), or when one wants to detect cytoplasmic RNAs.

After 2 washes in PBS, cells are permeabilized by treatment with $70 \%$ ethanol for at least overnight at $4^{\circ} \mathrm{C}$.

Remark: Cover slips can be stored for weeks at this stage.

\section{Hybridization}

Cells are rehydrated for $5 \mathrm{~min}$ at room temperature in $2 \mathrm{X}$ SSC (300 mM NaCl, $30 \mathrm{mM}$ sodium citrate, $\mathrm{pH} 7.0$ ), $50 \%$ formamide. Cells are hybridized overnight at $37^{\circ} \mathrm{C}$ in $40 \mu \mathrm{l}$ of a mixture containing $10 \%$ dextran sulfate, $2 \mathrm{mM}$ vanadylribonucleoside complex, $0.02 \%$ RNAse-free BSA, $40 \mu \mathrm{g}$ E.coli tRNA, 2X SSC, $50 \%$ formamide, and $30 \mathrm{ng}$ of probe.

Remark: The amount of probe can be diminished if background hybridization is observed.

\section{Washing}

Cells are washed twice for $30 \mathrm{~min}$ at the appropriate stringency: $2 \mathrm{X} \mathrm{SSC,} 50 \%$ formamide, $37^{\circ} \mathrm{C}$ for oligonucleotide probes; $0.1 \mathrm{XSSC}, 50 \%$ formamide, $50^{\circ} \mathrm{C}$ for RNA probes.

Remark: Washing conditions may be adjusted for each probe, and can be optimized by Northern blotting. Probes that are labeled to a high specific activity (see below) tend to give higher background, but addition of $0.1 \%$ NP40 or $0.1 \%$ SDS in the washing buffer can diminish this background.

\section{RNAse Treatment (Optional)}

RNAse treatment can remove background binding of the probes. It is however better to avoid it when possible, since it leads to loss of RNA from the cells. In most cases, it is possible to remove the background by adjusting the stringency of washing and the amount of probe in the hybridization mixture.

\section{Antibody Detection (Optional)}

Digoxigenin-labeled probes can be detected with sheep anti-digoxigenin antibodies (1/200, Boehringer Mannheim), and then with donkey anti-sheep antibodies conjugated to fluorescein (1/150, Sigma). Slides are incubated for $1 \mathrm{~h}$ at $37^{\circ} \mathrm{C}$ in $2 \mathrm{X}$ SSC, $8 \%$ formamide, $2 \mathrm{mM}$ vanadylribonucleoside complex, 0.2\% RNAse-free BSA, and washed twice for $15 \mathrm{~min}$ in $2 \mathrm{XSSC}, 8 \%$ formamide at room temperature.

Remark: Fluorescent antibodies tend to give a high background, which is efficiently removed by the presence of $8 \%$ formamide in the incubation buffer. Mounting

Slides are washed in $1 \mathrm{X}$ PBS, and mounted in $90 \%$ glycerol, PBS, $1 \mathrm{mg} / \mathrm{ml}$ p-phenylendiamine, $0.1 \mathrm{mg} / \mathrm{ml}$ DAPI. 


\section{In Situ Hybridization of Yeast Cells (RNA and Oligonucleotide Probes)}

\section{General Considerations}

In situ hybridization of yeast cells is almost identical to mammalian cells, except that the cell wall has to be removed by spheroplasting the cells prior to hybridization.

\section{Fixation}

Yeast are grown in $45 \mathrm{ml}$ cultures in the appropriate media until they reach early log phase $\left(O D_{600}\right.$ between 0.2 and 0.4). Cells are fixed for $10 \mathrm{~min}$ at room temperature by directly adding to the medium $10 \mathrm{ml}$ of $20 \%$ formaldehyde, $50 \%$ acetic acid. The fixative is removed by three rounds of centrifugation (5 min at $3500 \mathrm{rpm}$ and at $4^{\circ} \mathrm{C}$ ), and resuspended in $10 \mathrm{ml}$ of ice-cold buffer $\mathrm{B}(1.2 \mathrm{M}$ sorbitol, $0.1 \mathrm{M}$ potassium phosphate, $\mathrm{pH} 7.5$ ).

Remark: As in mammalian cells, acetic acid improves detection only of nuclear RNA. For oligo probes, it is not necessary, and cells can be fixed by adding $5 \mathrm{ml}$ of $40 \%$ formaldehyde to the culture medium, and incubating 40 min at room temperature.

\section{Spheroplasting}

Cells are resuspended in $1 \mathrm{ml}$ of buffer B containing 20 $\mathrm{mM}$ Vanadyl-ribonucleoside complex, $28 \mathrm{mM}$ Bmercaptoethanol, $0.06 \mathrm{mg} / \mathrm{ml} \mathrm{PMSF}$, and transferred to a tube containing $0.1 \mathrm{mg}$ of dried oxalyticase. Spheroplasting is done by incubating the cells for $8 \mathrm{~min}$ at $30^{\circ} \mathrm{C}$. Cells are then centrifugated $2 \mathrm{~min}$ at $3500 \mathrm{rpm}$ at $4^{\circ} \mathrm{C}$, and washed once in ice-cold buffer $\mathrm{B}$. Cells are further resuspended in $650 \mu \mathrm{l}$ of buffer $\mathrm{B}$, and $100 \mu \mathrm{l}$ is added to poly-lysine coated cover slips (this is most easily performed in 6 well tissue culture plates, one cover slip per well). Cells are left to adhere to the cover slip by incubating them $30 \mathrm{~min}$ at $4^{\circ} \mathrm{C}$. $3 \mathrm{ml}$ of buffer B is then carefully added to each well, removed by suction, and replaced by $5 \mathrm{ml}$ of $70 \%$ ethanol, which is incubated at least overnight at $-20^{\circ} \mathrm{C}$. At this stage, the cover slips can be stored for weeks at $-20^{\circ} \mathrm{C}$.

\section{Hybridization and Washing}

These steps are the same as for mammalian cells.

\section{Preparation of Probes for In Situ Hybridization}

\section{DNA Oligonucleotide Probes}

DNA oligonucleotides are presently the best probes for in situ hybridization. They are chemically synthesized which allows for the incorporation of amino-modified nucleotides (amino-allyl T) at defined positions in the sequence. These free amines are chemically coupled to fluorophores after synthesis. The modified Ts should be about 10 bases apart so as not to prevent binding of the probe to its target. The GC content of the oligo should be around $50 \%$, its length can be variable, but 50 bases (i.e. 5 flurochromes per molecule of probe) works well in most cases. The signal can be further increased by using several different oligonucleotides against the same RNA.

After synthesis, the oligo should be purified by either gel electrophoresis or reverse chromatography on C-18 Sep-pack columns (Waters). Oligos are then conjugated to activated fluorophores as described below.
RNA Probes

RNA probes are synthesized by in vitro transcription with T3, T7 or Sp6 RNA polymerases. The fluorescent label can be incorporated during transcription (following manufacturer instructions), by using nucleotides that are already coupled to fluorophores. Unfortunately, these nucleotides are incorporated at a low frequency and the resulting specific activity of these probes is consequently sequence dependant and low, i.e. less than 1 molecule of fluorophore per 100 transcribed bases. Importantly, these transcription reactions cannot be phenol extracted since the labeled RNAs partition with the phenolic phase.

Alternatively, the fluorescent label can be chemically conjugated to the RNA after probe synthesis, and this can result in specific activities as high as 1 fluorophore per 10 bases transcribed. To accomplish this, RNAs are synthesized by standard in vitro transcription reactions, except that UTP is replaced by an equal concentration of amino-allyl UTP (Sigma), or by a mixture of UTP/aminoallyl UTP (usually at a 1/1 ratio). Unlike fluorescent nucleotides, amino-allyl nucleotides are incorporated almost as well as unmodified UTP. Transcription reactions are then phenol extracted, RNA is ethanol precipitated, resuspended in $1 \mathrm{X}$ SSC, and unincorporated nucleotides are removed by two rounds of gel filtration (1X SSC buffered P30 micro-spin column, BioRad). The RNA is again ethanol precipitated and resuspended in water.

Remark: It is very important to design RNA probes such that no polylinker sequences are present in the resulting transcript since the polylinkers often contain GC rich stretches that induce cross-hybridization with ribosomal RNA (38).

\section{Chemical Conjugation of the Amino-Modified Nucleic Acids} with Activated Fluorophores

The nucleic acid to be labeled should be resuspended in $70 \mu$ l of $0.1 \mathrm{M} \mathrm{NaHCO}_{3}$ buffer, $\mathrm{pH}$ 8.8. Different amounts of material will result in different specific activities of the probe. $5-10 \mu \mathrm{g}$ of nucleic acid will yield a high specific activity $(60-80 \%$ of the free amine will react), while $50 \mu \mathrm{g}$ will yield a lower activity (5-20\% of the free amine will be conjugated). Labeling is initiated by adding $30 \mu \mathrm{l}$ of DMSO containing the activated fluorophore. In principle, any amine reactive compound could be used. In practice, CY3 (1 vial of monoreactive labelling kit per reaction, Amersham), works very well as a red fluorophore, and the succinimidyl ester of Oregon green 488 (1mg of compound per reaction, Molecular Probes) works well as a green dye. Labeling is then conducted for $24-48 \mathrm{~h}$ in the dark, at room temperature, with occasional vortexing.

Remark: Any trace of free amine, such as Tris base, should be removed from the nucleic acid, as it will also react with the fluorophore.

Unreacted dye is removed by either two rounds of ethanol precipitation and washing (carrier IRNA can be added if needed), or by gel filtration through G50 columns. Specific activity of the probes is calculated by absorption spectroscopy.

Remark: It is usually desirable to incorporate as many fluorophores per molecule of probe as possible, but it 
should be noted than more than 4-5 molecules of dye per probe tend to result in a high background during in situ hybridization.

\section{Further Reading}

Rossi, J.J. and Couture, L.A. 1999. Intracellular Ribozyme Applications: Principles and Protocols. Horizon Scientific Press, Wymondham, UK.

\section{References}

1. Jaeger, L. 1997. The new world of ribozymes. Curr. Opin. Struct. Biol. 7: 324-335.

2. Haseloff, J., and Gerlach, W. 1988. Simple RNA enzymes with new and highly specific endoribonuclease activities. Nature. 334: 585-591.

3. Stage-Zimmermann, T., and Uhlenbeck, O. 1998. Hammerhead ribozyme kinetics. RNA. 4: 875-889.

4. Bertrand, E., Castanotto, D., Zhou, C., Carbonnelle, C., Lee, N., Good, P., Chatterjee, S., Grange, T., Pictet, R., Kohn, D., Engelke, D., and Rossi, J. 1997. The expression cassette determines the functional activity of ribozymes in mammalian cells by controlling their intracellular localization. RNA. 3: 75-88.

5. Bertrand, E., Pictet, R., and Grange, T. 1994. Can hammerhead ribozymes be efficient tools to inactivate gene function? Nucl. Acids Res. 22: 293-300.

6. Hertel, K., Herschlag, D., and Uhlenbeck, O. 1994. A kinetic and thermodynamic framework for the hammerhead ribozyme reaction. Biochem. 33: 3374-3385.

7. Bertrand, E., and Rossi, J. 1994. Facilitation of hammerhead ribozyme catalysis by the nucleocapsid protein of HIV-1 and the heterogeneous nuclear ribonucleoprotein A1. EMBO J. 13: 2904-2912.

8. Hendry, P.M.M. 1996. Unexpected anisotropy in substrate cleavage rates by asymmetric hammerhead ribozymes. Nucl. Acids Res. 24: 2679-2684.

9. Clouet-d'Orval, B., and Uhlenbeck, O. 1997. Hammerhead ribozymes with a faster cleavage rate. Biochem. 36: 9087-9092.

10. Hertel, K., Pardi, A., Uhlenbeck, O., Koizumi, M., Ohtsuka, E., Uesugi, S., Cedergren, R., Eckstein, F., Gerlach, W., Hodgson, R., and Symons, R. 1992. Numbering system for the hammerhead. Nucl. Acids Res. 20: 3252.

11. Heidenreich, O., and Eckstein, F. 1992. Hammerhead ribozymemediated cleavage of the long terminal repeat RNA of human immunodeficiency virus type 1. J. Biol. Chem. 267: 1904-1909.

12. Donahue, C., and Fedor, M. 1997. Kinetics of hairpin ribozyme cleavage in yeast. RNA. 3: 961-973.

13. Samarsky, D., Ferbeyre, G., Bertrand, E., Singer, R., Cedegren, R., and Fournier, M. 1999. A snoRNA:ribozyme hybrid cleaves a nucleolar RNA target in vivo with near-perfect efficiency. Proc. Natl. Acad. Sci. USA. 96: 6609-6614.

14. Sullenger, B., and Cech, T. 1993. Tethering ribozymes to a retroviral packaging signal for destruction of viral RNA. Science. 262: 15661569.

15. Ilves, H., Barsk,e C., Junker, U., Bohnlein, E., and Veres, G. 1996. Retroviral vectors designed for targeted expression of RNA polymerase III-driven transcripts: a comparative study. Gene. 171: 203-208.

16. Yu, M., Ojwang, J., Yamada, O., Hampel, A., Rapapport, J., Looney, D., and Wong-Staal, F. 1993. A hairpin ribozyme inhibits expression of diverse strains of human immunodeficiency virus type 1. Proc. Natl. Acad. Sci. USA. 90: 6340-6344.

17. Good, P., Krikos, A., Li, S., Bertrand, E., Lee, N., Giver, L., Ellington, A., Zaia, J., Rossi, J., and Engelke, D. 1997. Expression of small, therapeutic RNAs in human cell nuclei. Gene Ther. 4: 45-54.

18. Cagnon, L., Cucchiarini, M., Lefebvre, J., and Doglio, A. 1995. Protection of a T-cell line from human immunodeficiency virus replication by the stable expression of a short antisense RNA sequence carried by a shuttle RNA molecule. J. Acquir. Immune Defic. Syndr. Hum. Retrovirol. 9: 349-358.

19. Cotten, M., and Birnstiel, M. 1989. Ribozyme mediated destruction of RNA in vivo. EMBO J. 8: 3861-3866.

20. Michienzi, A., Prislei, S., and Bozzoni, I. 1996. U1 small nuclear RNA chimeric ribozymes with substrate specificity for the Rev pre-mRNA of human immunodeficiency virus. Proc. Natl. Acad. Sci. USA. 93: 7219-7224.

21. Prislei, S., Buonomo, S., Michienzi, A., and Bozzoni, I. 1997. Use of adenoviral VAI small RNA as a carrier for cytoplasmic delivery of ribozymes. RNA. 3: 677-678.

22. Ruiz, J., Wu, C., Ito, Y., and Wu, G. 1997. Design and preparation of a multimeric self-cleaving hammerhead ribozyme. Biotechniques. 22: 338-345.

23. L'Huillier, P., Davis, S., and Bellamy, A. 1992. Cytoplasmic delivery of ribozymes leads to efficient reduction in alpha-lactalbumin mRNA levels in C127I mouse cells. EMBO J. 11: 4411-4418.

24. Ferbeyre, G., Smith, J., and Cedergren, R. 1998. Schistosome satellite DNA encodes active hammerhead ribozymes. Mol. Cell. Biol. 18: 38803888.

25. Montgomery, R., and Dietz, H. 1997. Inhibition of fibrillin 1 expression using U1 snRNA as a vehicle for the presentation of antisense targeting sequence. Hum. Mol. Genet. 6: 519-525.

26. Perriman, R., Bruening, G., Dennis, E., and Peacock, W. 1995. Effective ribozyme delivery in plant cells. Proc. Natl. Acad. Sci. USA 92: 6175-6179.

27. Thompson, J., Ayers, D., Malmstrom, T., McKenzie, T., Ganousis, L., Chowrira, B., Couture, L., and Stinchcomb, D. 1995. Improved accumulation and activity of ribozymes expressed from a tRNA-based RNA polymerase III promoter. Nucleic Acids Res. 23: 2259-2268.

28. Pal, B., Scherer, L., Zelby, L., Bertrand, E., and Rossi, J. 1998. Monitoring retroviral RNA dimerization in vivo via hammerhead ribozyme cleavage. J. Virol. 72: 72: 8349-8353.

29. Girard, P., Bonnet-Mathoniere, B., Muriaux, D., and Paoletti, J. 1995. Auto complementary sequence in the $5^{\prime}$ leader region is responsible for dimerization of MoMuLV genomic RNA. Biochem. 34: 8705-8714

30. Smith, C., and Steitz, J. 1997. Sno storm in the nucleolus: new roles for myriad of small RNPs. Cell. 89: 669-672.

31. Maxwell, E., and Fournier, M. 1995. The small nucleolar RNAs. Annu. Rev. Biochem. 35: 897-934.

32. Bachellerie, J., and Cavaille, J. 1997. Guiding ribose methylation of rRNA. Trends Biochem. Sci. 22: 257-261.

33. Samarsky, D., and Fournier, M. 1998. Functional mapping of the U3 small nucleolar RNA from the yeast Saccharomyces Cervisiae. Mol. Cell. Biol. 18: 3431-3444.

34. Mereau, A., Fournier, R., Gregoire, A., Mougin, A., Fabrizio, P., Luhrmann, R., and Branlant, C. 1997. An in vivo and in vitro structurefunction analysis of the Saccharomyces cervisiae U3A snoRNP: protein-RNA contacts and base-pair interaction with the pre-ribosomal RNA. J. Mol. Biol. 273: 552-571.

35. Samarsky, D., Fournier, M., Singer, R., and Bertrand, E. 1998.The snoRNA box C/D motif directs nucleolar targeting and also couples snoRNA synthesis and localization. EMBO J. 17: 3747-3757.

36. Pederson, T. 1998. The plurifunctional nucleolus. Nucl. Acids Res. 26: $3871-3876$.

37. Ferbeyre, G., Bratty, J., Chen, H., and Cedegreb, R. 1996. Cell cycle arrest promotes trans-hammerhead ribizyme action in yeast. J. Biol. Chem. 271: 19318-19323.

38. Witkiewicz, H., Bolander, M.E., Edwards, D.R., 1993. Improved design of riboprobes from pBluescript and related vectors for in situ hybridization. Biotechniques. 14: 458-463.

39. Rossi, J.J. and Couture, L.A. 1999. Intracellular Ribozyme Applications: Principles and Protocols. Horizon Scientific Press, Wymondham, UK. 


\section{Further Reading}

Caister Academic Press is a leading academic publisher of advanced texts in microbiology, molecular biology and medical research. Full details of all our publications at caister.com

- MALDI-TOF Mass Spectrometry in Microbiology Edited by: M Kostrzewa, S Schubert (2016) www.caister.com/malditof

- Aspergillus and Penicillium in the Post-genomic Era Edited by: RP Vries, IB Gelber, MR Andersen (2016) www.caister.com/aspergillus2

- The Bacteriocins: Current Knowledge and Future Prospects Edited by: RL Dorit, SM Roy, MA Riley (2016)

www.caister.com/bacteriocins

- Omics in Plant Disease Resistance Edited by: V Bhadauria (2016) www.caister.com/opd

- Acidophiles: Life in Extremely Acidic Environments Edited by: R Quatrini, DB Johnson (2016) www.caister.com/acidophiles

- Climate Change and Microbial Ecology: Current Research and Future Trend

Edited by: J Marxsen (2016)

www.caister.com/climate

- Biofilms in Bioremediation: Current Research and Emerging Technologies

Edited by: G Lear (2016)

www.caister.com/biorem

- Microalgae: Current Research and Applications Edited by: MN Tsaloglou (2016) www.caister.com/microalgae

- Gas Plasma Sterilization in Microbiology: Theory, Applications, Pitfalls and New Perspectives Edited by: H Shintani, A Sakudo (2016) www.caister.com/gasplasma

- Virus Evolution: Current Research and Future Directions Edited by: SC Weaver, M Denison, M Roossinck, et al. (2016) www.caister.com/virusevol

- Arboviruses: Molecular Biology, Evolution and Control Edited by: N Vasilakis, DJ Gubler (2016) www.caister.com/arbo

- Shigella: Molecular and Cellular Biology Edited by: WD Picking, WL Picking (2016) www.caister.com/shigella

-Aquatic Biofilms: Ecology, Water Quality and Wastewater Treatment

Edited by: AM Romaní, H Guasch, MD Balaguer (2016)

www.caister.com/aquaticbiofilms

- Alphaviruses: Current Biology

Edited by: S Mahalingam, L Herrero, B Herring (2016)

www.caister.com/alpha

- Thermophilic Microorganisms

Edited by: F Li (2015)

www.caister.com/thermophile
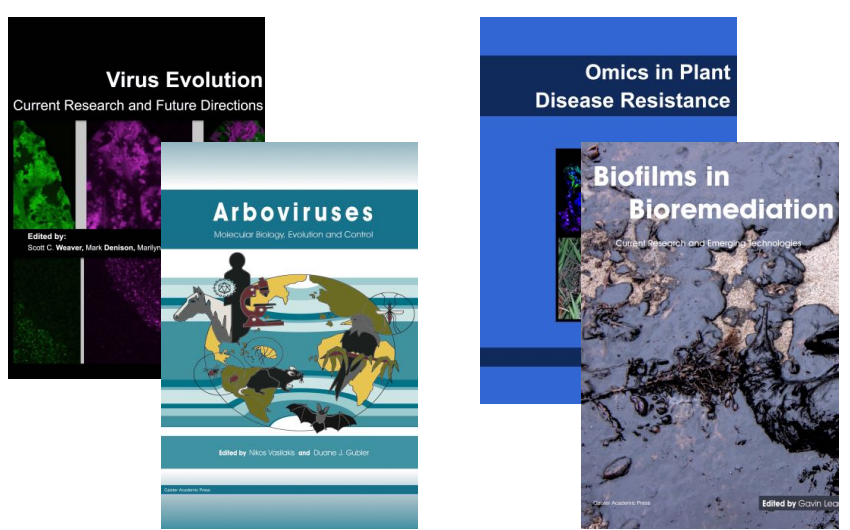
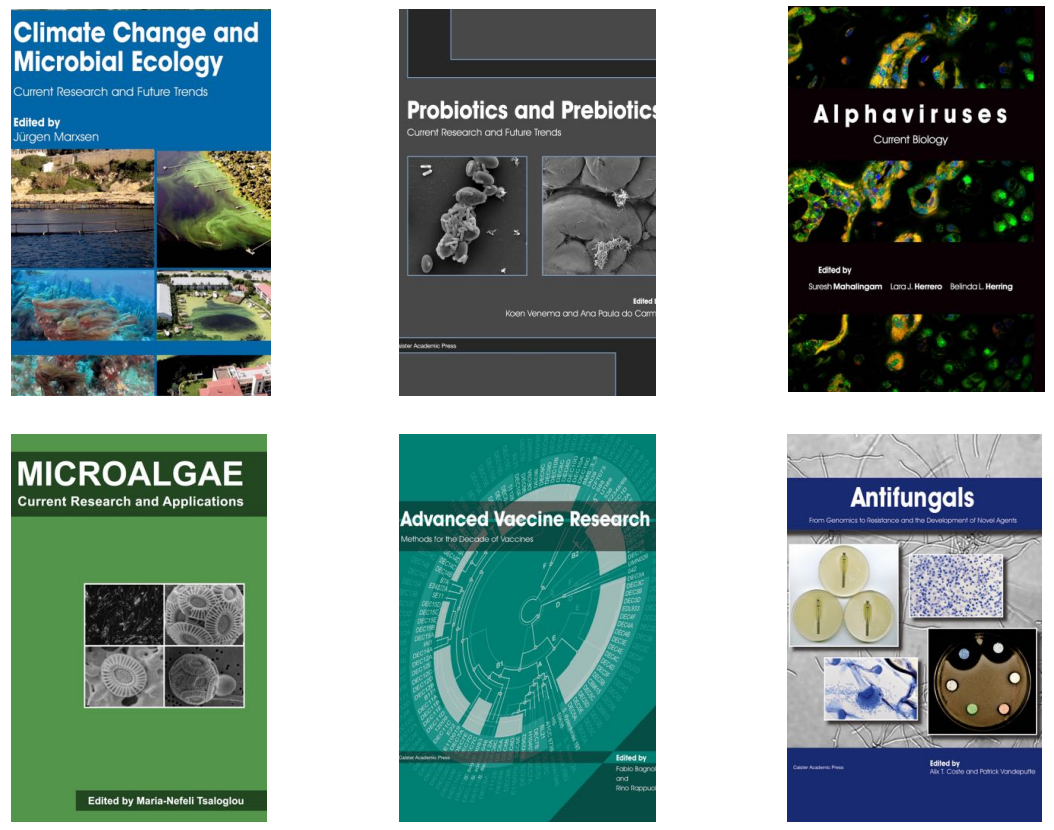

- Flow Cytometry in Microbiology: Technology and Applications Edited by: MG Wilkinson (2015) www.caister.com/flow

- Probiotics and Prebiotics: Current Research and Future Trends Edited by: K Venema, AP Carmo (2015) www.caister.com/probiotics

- Epigenetics: Current Research and Emerging Trends Edited by: BP Chadwick (2015) www.caister.com/epigenetics2015

- Corynebacterium glutamicum: From Systems Biology to Biotechnological Applications

Edited by: A Burkovski (2015)

www.caister.com/cory2

- Advanced Vaccine Research Methods for the Decade of Vaccines

Edited by: F Bagnoli, R Rappuoli (2015)

www.caister.com/vaccines

- Antifungals: From Genomics to Resistance and the Development of Novel Agents

Edited by: AT Coste, P Vandeputte (2015)

www.caister.com/antifungals

- Bacteria-Plant Interactions: Advanced Research and Future Trends Edited by: J Murillo, BA Vinatzer, RW Jackson, et al. (2015) www.caister.com/bacteria-plant

\section{- Aeromonas}

Edited by: J Graf (2015)

www.caister.com/aeromonas

- Antibiotics: Current Innovations and Future Trends

Edited by: S Sánchez, AL Demain (2015)

www.caister.com/antibiotics

- Leishmania: Current Biology and Contro Edited by: S Adak, R Datta (2015) www.caister.com/leish2

- Acanthamoeba: Biology and Pathogenesis (2nd edition) Author: NA Khan (2015)

www.caister.com/acanthamoeba2

- Microarrays: Current Technology, Innovations and Applications Edited by: Z He (2014)

www.caister.com/microarrays2

- Metagenomics of the Microbial Nitrogen Cycle: Theory, Methods and Applications

Edited by: D Marco (2014)

www.caister.com/n2 